
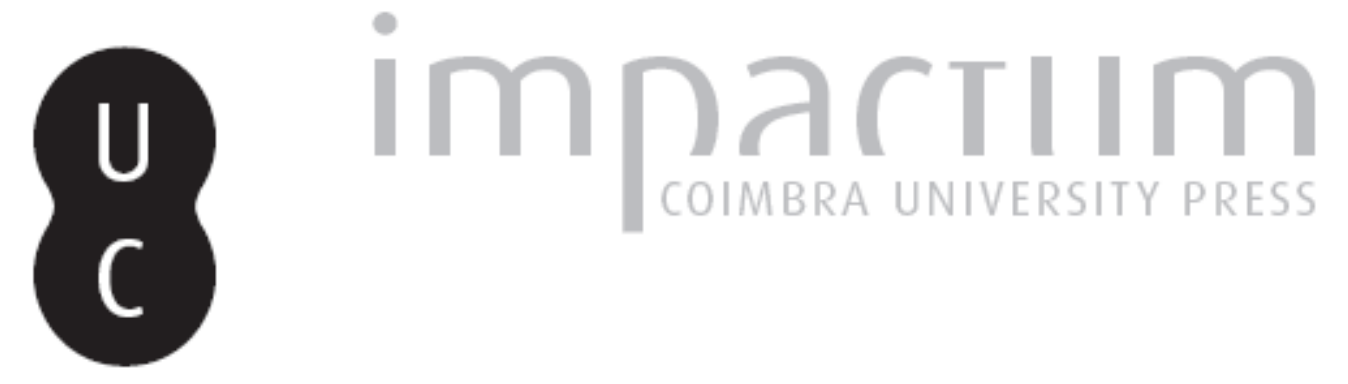

\title{
Katabasis e autossalvação na recriação do orfismo no Banquete de Platão
}

Autor(es): $\quad$ Coutinho, Luciano

Publicado por: Imprensa da Universidade de Coimbra

URL persistente:

URI:http://hdl.handle.net/10316.2/43368

DOI:

DOI:https://doi.org/10.14195/2183-7260_62_2

Accessed : $\quad$ 26-Apr-2023 09:45:20

A navegação consulta e descarregamento dos títulos inseridos nas Bibliotecas Digitais UC Digitalis, UC Pombalina e UC Impactum, pressupõem a aceitação plena e sem reservas dos Termos e Condições de Uso destas Bibliotecas Digitais, disponíveis em https://digitalis.uc.pt/pt-pt/termos.

Conforme exposto nos referidos Termos e Condições de Uso, o descarregamento de títulos de acesso restrito requer uma licença válida de autorização devendo o utilizador aceder ao(s) documento(s) a partir de um endereço de IP da instituição detentora da supramencionada licença.

Ao utilizador é apenas permitido o descarregamento para uso pessoal, pelo que o emprego do(s) título(s) descarregado(s) para outro fim, designadamente comercial, carece de autorização do respetivo autor ou editor da obra.

Na medida em que todas as obras da UC Digitalis se encontram protegidas pelo Código do Direito de Autor e Direitos Conexos e demais legislação aplicável, toda a cópia, parcial ou total, deste documento, nos casos em que é legalmente admitida, deverá conter ou fazer-se acompanhar por este aviso.

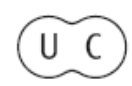


COIMBRA • 2017
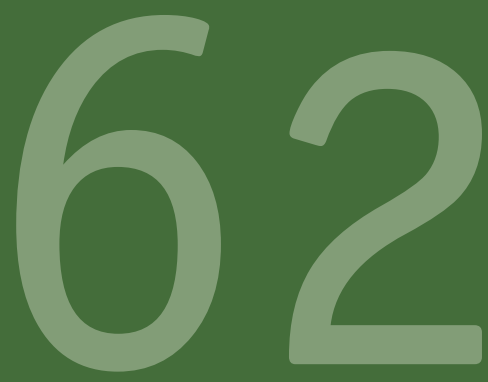

BOLETIM DE

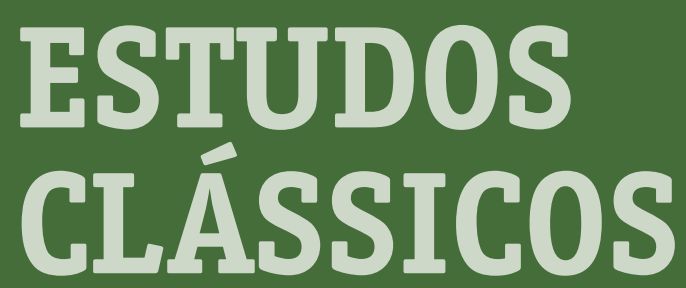

\author{
ASSOCIAÇÃO \\ PORTUGUESA \\ DE ESTUDOS \\ CLÁSSICOS \\ INSTITUTO \\ DE ESTUDOS \\ CLÁSSICOS
}




\title{
KATABASIS E AUTOSSALVAÇÃO NA RECRIAÇÃO DO ORFISMO NO BANQUETE DE PLATÃO
}

\author{
KATABASIS AND SELF-SALVATION \\ IN THE RECREATION OF THE ORPHISM IN PLATO'S SYMPOSIUM
}

\author{
LUCIANO COUTINHO ${ }^{1}$ \\ CECH - UNIVERSIDADE DO MINHO \\ lucianocoutinho1@gmail.com \\ ORCID.0RG/0000-0003-3868-9950
}

ARTIG0 RECEBID0 A 13-04-2017 E APROVADO A 17-06-2017

Resumo: A temática de salvação da alma no Hades é bastante recorrente na tradição órfica. Platão recria esta imagem órfica, no Banquete, com o intuito de alterar a ideia órfica de salvação/resgate de uma alma (que é dada por uma divindade, nomeadamente Orfeu) em uma imagem que reforça sua teoria da responsabilidade psíquica, com a ideia de que cada psyche só pode salvar-se a si própria. Para tanto, a famosa descida de Orfeu para resgatar sua amada Eurídice da morte no Hades é alterada por Platão por uma imagem de completo fracasso: os deuses

1 Luciano Coutinho é Doutor em Estudos Clássicos / Filosofia Antiga pela Universidade de Coimbra - UC (bolsista CAPES para Doutorado Pleno no Exterior). É Mestre em Filosofia Antiga pela Universidade de Brasília - UnB (bolsista CAPES). É Mestre em Arquitetura e Urbanismo (com ênfase em Estética e Semiótica) pela Universidade de Brasília - UnB. Realizou Pós-Doutoramento no Departamento de Filosofia da Universidade Federal de Uberlândia - UFU (com bolsa CAPES/Procad). Atualmente, está a realizar Pós-Doutoramento no Departamento de Filosofia da Universidade do Minho. 
do Hades oferecem a Orfeu apenas o fantasma de Eurídice e não sua psyche, como quem paga ilusão com decepção. Ao tentar enganar as instâncias divinas com meros encantamentos superficiais, Orfeu recebe dos deuses o maior dos enganos: uma imagem fantasmagórica de sua amada. Tentaremos, neste trabalho, demonstrar como essa recriação platônica da katabasis e da salvação órficas sustenta a ideia de que nenhum ente teria o poder de salvar um outro ente da obscuridade, pois cada psyche só é capaz de salvar-se a si própria.

Palavras-chave: Orfismo; Platão; Recriação do Orfismo; Katabasis; Autossalvação.

Abstract: The topic of the soul's salvation in Hades is very recurrent in the Orphic tradition. In the Symposium, Plato recreates this Orphic image in order to modify the Orphic idea of the soul's salvation/rescue (which is given by a divinity, namely Orpheus) into an image that reinforces his theory of psychic responsibility, with the idea that any psyche is able of self-salvation. Therefore, the famous Orphic descent to Hades to rescue his beloved Eurydice from death is modified by Plato into an image of complete failure: the gods of Hades offer Orpheus only the ghost of Eurydice rather than her psyche, as if to pay illusion with deception. As he tried to deceive the divinities with superficial enchantments, Orpheus receives from the gods the biggest of all delusions: a phantasmagorical image of his beloved one. This paper aims to demonstrate how this platonic recreation of the orphic katabasis and the orphic salvation supports the idea that no entity would have the power to save another entity from obscurity, since every psyche is able of self-salvation.

Keywords: Orphism; Plato; Recreation of Orphism; Katabasis; Self-salvation. 


\section{APRESENTAÇÃ0 DO PROBLEMA ${ }^{2}$}

A katabasis de Orfeu é, sem dúvida, um elemento mítico fundamental na busca platônica por uma teoria acerca do melhoramento da psyche humana. Para compreendermos tal questão, faremos uma comparação entre imagens de katabasis (descida) ligadas a Orfeu, segundo conta a tradição, e a recriação de tais imagens em Platão. ${ }^{3}$

Veremos que, nos mitos ligados a Orfeu, a imagem de katabasis surge ora associada ao resgate de sua amada Eurídice do Hades ora não associada a esse feito. Mas, de fato, o que se repete nas duas variantes é o estatuto de intervenção que Orfeu exerceria com seus poderes de encantamento no Hades. É em torno de tais poderes que o(s) orfismo(s) fundamenta(m) a crença na capacidade de interferência no destino das almas no Além, por meio de práticas rituais de iniciação.

Ao contrário dessa visada, Platão faz sua personagem Sócrates utilizar-se dessas ideias órficas para sustentar que os crimes cometidos por uma alma não são sanados por ritual, em primeiro lugar, e, em segundo lugar, não são sanados por um outro ente que não seja a própria alma que cometera os crimes. É contra a ideia de que uma alma poderia ser livrada do julgamento por intervenção de um outro

2 Este artigo foi desenvolvido a partir da revisão e do redirecionamento de estudos e de partes da Tese Doutoral intitulada Katabasis e psyche em Platão, defendida com "Distinção e Louvor por Unanimidade" na Universidade de Coimbra - UC.

3 Comentadores como Casadesús, por exemplo, percebem com propriedade que "Platón, de un modo parecido a como lo hicieran los pitagóricos, incorporó en su propio sistema filosóficos numerosos elementos órficos, relacionados principalmente con la noción de inmortalidad del alma y su destino en el Más Allá” (Casadesús 2006: 160). Bernabé diz ainda que Platão "faz uso de algumas doutrinas órficas, aplicando generosamente sobre a mensagem antiga os métodos de transposição a que me referi no $\S$ 13, enquanto que, com relação a outras, se limita a fugir da grosseria e superficialidade dos conteúdos transmitidos pelos orfeutelestas (Bernabé 2011: 409). Comungando com Casadesús e Bernabé, acrescento apenas a ideia de que Platão não apenas adapta as ideias míticas a seus sistemas filosóficos, mas (re)cria seus próprios mythoi a partir de mythoi originários, para com o resultado dado pelas diferenças entre os mythoi originários e os mythois recriados por ele representar suas teses filosóficas (Coutinho 2015b: 31-37). 
ente (por meio de poderes encantados) que Platão recria a descida de Orfeu no Banquete. É nesse sentido que, para a personagem Sócrates, nem Orfeu nem qualquer outro ente poderia salvar uma alma do Hades, mas antes, cada alma só poderia salvar-se a si própria.

Platão, com isso, chama atenção para o fato de que cada psyche deve melhora-se a si própria, não por ritual, mas antes por mudança de caráter, já que ninguém poderia fazê-lo por ela. Salvação, nesse sentido, é uma referência ao melhoramento psíquico/mental de cada indivíduo. E ser salvo ou resgatado no contexto socrático e órfico no interior do diálogo, portanto, é antes uma imagem para a ideia de (auto)melhoramento.

Dividiremos este artigo em duas partes: 1) a primeira tratará de imagens míticas da tradição em torno da descida de Orfeu ao Hades; 2) a segunda tratará das imagens de Orfeu recriadas por Platão, em especial, no Banquete.

Será possível, com isso, comparar e verificar as alterações propostas por Platão, e, assim, buscar compreender, pelas diferenças entre essas imagens, a teoria platônica em torno do melhoramento da psyche humana por meio de uma katabasis subjetiva, ou se preferirmos, katabasis psíquica e não por meio de uma katabasis objetiva como no mito órfico.

\section{1 - ORFEU E SEUS PODERES MÍTICOS DE KATABASIS}

Uma das imagens mais sintomáticas de poder divino no plano ínfero da existência está descrita por Heródoto:

Os Egípcios dizem que Ceres e Baco possuem um poder soberano nos infernos. Foi também esse povo o primeiro a afirmar que a alma do homem é imortal e que, morto o corpo, transmigra sempre para o de qualquer animal; e depois de haver passado assim, sucessivamente, por todas as espécies de animais terrestres, aquáticos e voláteis, torna 
a entrar num corpo de homem, realizando-se essas diferentes transmigrações no espaço de três mil anos. Sei que alguns Gregos esposaram essa opinião, uns mais cedo, outros mais tarde, considerando-a como sua. Não ignoro seus nomes, mas prefiro não mencioná-los (Hdt. Hist. $2,123){ }^{4}$

A respeito desta afirmação, Bernabé está convicto de que os nomes não mencionados por Heródoto estão ligados à tradição órfica:

Sabemos, não obstante, que no Egito o mito de Osiris não era secreto e que não se celebravam autênticos mistérios em honra ao deus, razão pela qual as precauções de Heródoto foram interpretadas no sentido de que na Grécia, na época do historiador, se contava nos mistérios báquicos uma história muito similar ao do deus egípcio: o desmembramento de Dionísio" (Bernabé 2007: 56). ${ }^{5}$

Semelhante a esse relato de Heródoto, Diodoro Siculo (D. S. 1, 92, 3) afirma que Orfeu teria trazido do Egito a maioria dos ritos iniciáticos e as celebrações orgiásticas que acompanham sua peregrinação e suas histórias sobre o Hades. Para Macías (2008: 313), essa informação de Siculo é apenas uma tentativa de aproximar a religião grega da egípcia.

O fato é que os poderes de Orfeu ficam consagrados na tradição. Suas capacidades de encantar tornam-se famosas entre os gregos. ${ }^{6}$ Píndaro, por exemplo, menciona Orfeu como pai dos cantos - "E da parte de Apolo, chegou o citarista, pai dos cantos, / o bem-afamado

4 Trad. de Larcher (2006).

5 "Sabemos, no obstante, que en Egipto el mito de Osiris no era secreto y que no se celebraban en honor del dios auténticos misterios, razón por la cual las precauciones de Heródoto se han interpretado en el sentido de que en Grecia, en época del historiador, se contaba en los misterios báquicos una historia muy similar a la del dios egipcio: el desmembramiento de Dioniso". Cf. também Burkert (1983: 225, n. 43); Kahn (1997: 57).

6 O poeta Íbico de Régio (séc. VI a.C.) já mencionava a fama de Orfeu na antiguidade (Ibyc. Adrados fr. 26). 
Orfeu" (Pi. Piítica 4, 176s) (OF 899 I) ${ }^{7}$-, e isso está diretamente ligado ao seu poder de encantamento por meio da música.

Em Ifigênia em Áulis, de Eurípides, mesmo as pedras, que não compreendem a palavra humana, poderiam ser encantadas pelo canto de Orfeu. 0 verbo "encantar" ${ }^{8}$ utilizado por Eurípides (bastante recorrente no diálogo platônico que trata com exuberância questões relacionadas ao poder do encantamento: o Cármides $^{9}$ ), indica o poder mágico da divindade por meio do canto. Esse poder torna-se essencial na dramaticidade da tragédia de Eurípides, no momento em que Ifigênia, deseja o dom órfico de encantar "pedras", para convencer seu pai a não sacrificá-la (If. Au. v. 1212) $)^{10}$.

Nas Bacantes, Eurípides apresenta uma cena bastante representativa das capacidades que Orfeu tem para "congregar com música as árvores e os animais do campo" (E. Ba.vv. 563-564) ${ }^{11}$. O encanto de seu canto, de sua música, seria uma expressão mítica do inevitável domínio exercido sob outros entes. E este é o mote mítico que a tradição órfico-religiosa associa para a sustentação da ideia de que a iniciação órfica é capaz até mesmo de fazer o iniciado passar imunemente pelo julgamento no Além, já que tal encantamento poderia até mesmo encantar os deuses no Hades.

Quando associada à imagem de katabasis, a figura de Orfeu surge em um contexto em que ele apresenta poderes no plano ínfero. ${ }^{12}$ Orfeu parece possuir o conhecimento adequado para fazer as almas alcançarem o melhor destino, abrandando, no Hades, as potências divinas.

7 Trad. de Bernabé (2011: 419).

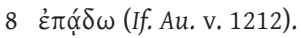

9 Cf. Cármides (155e5). Cf. Coutinho (2015a) a esse respeito.

$10 \dot{\omega} \sigma \theta^{\prime} \dot{o} \mu \alpha \rho \tau \varepsilon \tilde{\imath} v \mu o 1 \pi \dot{\varepsilon} \tau \rho \alpha \zeta$.

$11 \sigma \dot{u} v \alpha \gamma \varepsilon v \delta \dot{\varepsilon} v \delta \rho \varepsilon \alpha \mu \dot{v} \sigma \alpha \iota \varsigma / \sigma \dot{v} v \alpha \gamma \varepsilon v \theta \tilde{\eta} \rho \alpha \varsigma \alpha \dot{\alpha} \gamma \rho \dot{\omega} \tau \alpha \varsigma$.

12 Para o "panxamanismo" de Dodds, que aqui comungamos, Orfeu é um tipo de xamã mítico ou protótipo de xamã (Dodds 2002: 150). Isto nos ajuda a compreender os poderes de Orfeu em sua imersão catabática. 
Guthrie (2003: 81) chama atenção para o fato de que a crença órfica previa que Orfeu poderia interceder pelo bem de seus seguidores. Grosso modo, Guthrie chama atenção para a capacidade que Orfeu teria de interferir no destino de seus seguidores e a capacidade de abrandar as potências que julgam as almas no Hades. Assim, a ideia de iniciação órfica estende-se ao campo da purificação por meio ritual, ou seja, os rituais serviriam para a purificação e o melhoramento do destino das almas no Além. Apenas mais tarde (acreditamos que no período Clássico), estas ideias são associadas a um tipo de moralização, em que os seguidores iniciados de Orfeu que tivessem uma vida pura receberiam o auxílio de Orfeu no julgamento de suas almas no Além. ${ }^{13}$

A essa ideia de intercedência no Hades, Eurípides, em Alcestes, chega a associar a expressão "comover" (E. Alc. v. 359) ${ }^{14}$ aos poderes de Orfeu, para reforçar seu poder encantatório sobre as divindades do julgamento no Hades:

Se possuísse a língua e o canto de Orfeu,

de sorte que à filha de Deméter ou a seu esposo

pudesse comover com os meus hinos e arrebatar-te do Hades,

baixaria, e nem o cão de Plutão

nem Caronte, que com o remo acompanha as almas

poderiam me deter, até que levasse a tua vida à luz

(E. Alc. vv. 357-362) $)^{15}$

Dentro dessa perspectiva, o motivo mais comummente associado à descida de Orfeu ao Hades é a tentativa de recuperar sua amada

13 Guthrie (2003), todavia, não faz distinção entre a tradição órfica e as alterações órficas sugeridas pela filosofia, mais especificamente pelas recriações platônicas do orfismo em função das ideias teóricas acerca da psyche.

$14 \kappa \eta \lambda \dot{\varepsilon} \omega$. A expressão $\kappa \eta \lambda \dot{\varepsilon} \omega$ está associada à amansamento e ao encantamento; cf. Macías (2008: 80).

15 (OF 980). Trad. Bernabé (2011: 419). 
Eurídice da morte; motivo romantizado do mito bastante recorrente na tragédia e também na poesia. Embora esse tema não pareça estar nos primórdios do mito, ele assume incontestável importância em versões posteriores.

Nas descrições que traz Pausânias das cenas infernais pintadas por Polignoto não há menção da presença de Eurídice que possa explicar a situação (Paus. 10. 30. 6 = Kern, test. 69). Pode ser que aos olhos de alguns, seus seguidores, Orfeu tivesse ali [no Hades] uma posição estabelecida, de direito próprio por assim dizer. Não havia necessidade de supor nenhuma missão particular para dar conta de sua presença, pois para o tempo de Polignoto Orfeu era certamente o patrono de uma religião que dava o máximo peso ao dogma escatológico. Se se pode crer em Pausânias (e não há razão para duvidar de que, ao descrever coisas que ele mesmo havia visto, fosse um informante tão cuidadoso como é detalhado), esta é nossa mais antiga constância da presença de Orfeu dentre os mortos. No entanto, é bastante tardia, naturalmente, para oferecer a certeza de que o motivo conjugal, ainda que fosse uma adição posterior à história originária, deve ter sido adicionado muito antes dessa época (Guthrie 2003: 82). ${ }^{16}$

Mesmo que o motivo do resgate de Eurídice não esteja na origem do mito e tenha sido acrescido posteriormente, sua influência e importância

16 “En la descripción que trae Pausanias de las escenas infernales pintadas por Polignoto no hay mención de la presencia de Eurídice que pueda explicar la situación (Paus. 10. 30. 6 = Kern, test. 69). Puede ser que a los ojos de algunos, sus seguidores, Orfeo tuviera allí una posición establecida, de derecho propio por así decirlo. No había necesidad de suponer ninguna misión particular para dar cuenta de su presencia, pues para el tiempo de Polignoto Orfeo era ciertamente el patrono de una religión que daba el máximo peso al dogma escatológico. Si ha de creerse a Pausanias (y no hay razón para dudar de que, al describir cosas que él mismo había visto, fuese un informante tan cuidadoso como lo es detalhado), ésta es nuestra más antigua constância de la presencia de Orfeo entre los muertos. Sin embargo, es lo bastante tardía, naturalmente, para ofrecer la certidumbre de que el motivo conyugal, aun si fuese una adicón posterior a la historia originaria, deba haberse añadido mucho antes de esa época". 
não podem ser negadas, já que demonstra o mote central em torno de Orfeu: a ideia de sua força e de sua influência no plano ínfero.

Uma última consideração acerca da katabasis ligada ao mito de Orfeu é que, segundo a tradição mítica, Orfeu teria descido ao Hades de maneira objetiva, ou seja, a descida de Orfeu é apresentada segundo uma descida propriamente dita. Orfeu, nas imagens míticas, desceria, de fato, ao Hades e nele exerceria seus poderes e influências. Assim, buscaremos demonstrar como Platão fundamenta sua teoria acerca do poder que a psyche tem de decidir sobre seu próprio destino a partir da alteração da katabasis objetiva em katabasis subejtica. ${ }^{17}$

Dito de outra maneira, Platão não comunga com a ideia de que uma divindade pode salvar uma psyche dos crimes que cometeu, menos ainda com a ideia de que um ritual, por si, é capaz de purificar uma psyche. Para Platão, cada psyche pode salvar-se a si própria. O canto encantatório não é a causa de purificação, mas antes e apenas um auxílio externo para que internamente a psyche possa alcançar sua temperança e, assim, purificar-se por meio de um auto-mergulho.

Analisaremos, portanto, na próxima parte, o caso do Orfeu do Banquete, de Platão. Nele, sua descida é associada diretamente ao tema do amor por Eurídice e sua tentativa de resgatá-la da morte no Hades.

\section{2 - A KATABASIS DE ORFEU NO BANQUETE DE PLATÃO}

Por meio de Fedro, Platão faz Orfeu, no Banquete, falhar em seu intento de resgatar sua amada Eurídice do Hades. É com essa alteração, em relação à tradição mítica, que Platão fundamenta a ideia da psyche como responsável pelo seu próprio destino, e não a divindade ou qualquer princípio ritual.

17 Cf. Coutinho (2015b). 
A ironia por trás do fracasso de Orfeu em resgatar sua amada, no diálogo, revela dois pontos fundamentais para a teoria da responsabilidade da psyche acerca de seu próprio destino em Platão: a alteração da katabasis objetiva de Orfeu em uma katabasis subjetiva feita pela psyche; e a alteração da imagem de resgate de uma alma no Hades em uma ideia de autossalvação psíquica. Estas duas questões serão analisadas a seguir.

\section{1- A FLAUTA E 0 ÁLCOOL}

No Banquete, o processo de embriaguez é reforçado pela flauta, instrumento que é associado a um certo poder de encantamento. Erixímaco pede que a flautista se retire, depois da decisão de que não haveria limite estipulado de álcool para o simpósio; isto sugere que a embriaguez não será reforçada. ${ }^{18}$

Aristófanes dá-nos sinais de como o instrumento está ligado aos ritos órficos:

Héracles: Daí para a frente vai-te envolver um som de flautas, e hás-de ver uma luz maravilhosa, como a daqui. Seguem-se bosques de mirto, cortejos ${ }^{19}$ bem-aventurados de homens e mulheres e um grande estrépito de palmas.

Dioniso: E esses, quem são?

Héracles: Os iniciados... ${ }^{20}$

(Ar. As Rãs vv. 153-158) ${ }^{21}$

18 Cf. Banquete (176e).

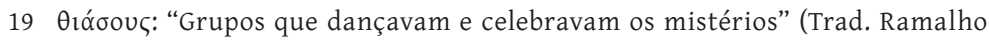

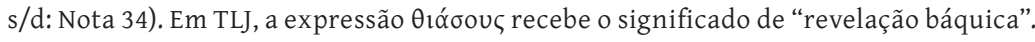

20 A expressão "Oi $\mu \varepsilon \mu u \eta \mu \varepsilon ́ v o l$ é traduzida como "Os iniciados nos mistérios" tanto na trad. de Ramalho (s/d) como em TLJ.

21 Trad. de Silva (2014). 
Píndaro, por exemplo, sugere um orfismo marcado pela suavidade e pela beleza que os bem-aventurados gozam no Além com o som da $\operatorname{lira}^{22}$. Orfeu é comumente ligado à lira e ao canto, mas não se pode deixar de mencionar sua ligação com a flauta.

Orfeu seria capaz de entoar um canto semelhante à doçura de uma flauta ou de uma lira, e, assim, seria capaz de encantar animais selvagens e até seres inanimados. Macías observa a ligação do luto de Admeto $^{23}$ e o som do canto flautado e o mito de Orfeu em Alceste, de Eurípides: "Que na cidade não haja som de flautas nem de lira até que doze luas tenham decorrido" (E. Alc. vv. 430-431) ${ }^{24}$. Isto pouco antes de fazer referência ao mito de Orfeu. Ao despedir-se de Alceste, Admeto anuncia um tipo de proibição das festas em seu palácio. Em meio a essa proibição, o canto com som de flauta surge como um elemento associado ao prazer da vida. Assim, o palácio e a cidade são chamados à racionalidade, para uma postura que seria adequada ao momento de tristeza. Além, é claro, da inferência que podemos fazer de que a alma poderia ser encantada pelo som e não digirir-se a seu destino.

No Banquete, Erixímaco age de modo semelhante, embora em um contexto festivo, longe de qualquer referência à tristeza, ao pedir que a flautista se retire para que se dê início o simpósio (Smp. 176e). A intenção é chamar os participantes à racionalidade, já que o contexto em que se dará o simpósio foi colocado sob condições amenas: a quantidade de vinho não é estipulada, para que não haja obrigatoriedade de embriaguez dos participantes.

22 Píndaro faz uma representação da vida pós-morte dos bem-aventurados: "Dentre os prados floridos, as ocupações deleitosas e as cerimonias piedosas, surge o som da lira" (Pi. fr. 129).

23 “Terminaré con los banquetes, las conversaciones de los invitados, las coronas y el arte de las Musas que se apoderaban de mi palacio. Pues jamás tocaré ya la lira, ni impulsaré mi ánimo a cantar al son de la flauta libia, pues tú me has arrebatado el placer de la vida" (E. Alc. vv. 343-347), trad. de Macías (2008: 49).

24 "Que en la ciudad no haya sonido de flautas ni de lira hasta que hayan transcurrido doce lunas", trad. de Macías (2008: 49). 
A flauta é um elemento que surge em destaque para ser retirado de cena. A referência de Platão a esse instrumento deixa clara a capacidade de retirar os participantes do discurso investigativo e conduzi-los a um plano de encantamento, mágico de embriaguez, causando efeitos semelhantes àqueles que Orfeu causaria a seus ouvintes. Retirar a flauta da dramaturgia indica tirar o clima órfico de cena, para que a reflexão tenha, apesar do álcool, o máximo possível de sobriedade. A possibilidade de encantamento é, nesse sentido, diminuída. A resistência alcoólica da personagem Sócrates sugere essa questão: acometido pelo álcool, mas não pela flauta, ele não se embriaga.

O diálogo sugere ainda que Sócrates é capaz de beber sem se embriagar, pelo menos quando distanciado dos encantados da flauta, e isso sugere seu distanciamento dos encantamentos psíquicos alheios à filosofia, como é o caso dos encantamentos órficos. Isto sugere, por sua vez, que Sócrates tem um elevado grau de temperança, e que apenas essa temperança é capaz de evitar os excessos da psyche e, por consequência, do soma. Enquanto o álcool é considerado um elemento externo que auxilia a psyche a uma certa sintonia com o conteúdo profundo do simpósio, a flauta é associada a um tipo de encantamento externo capaz de tirar a psyche de si própria, fazendo todo tipo de discurso perder o conteúdo profundo, permanecendo, assim, na superficialidade da musicalidade das palavras.

Essa ideia contida no Banquete, surge no Protágoras (315a-b), por exemplo, sob uma comparação entre o sofista e Orfeu. A prática de seduzir $^{25}$ a psyche dos ouvintes pela palavra é associada tanto a um quanto a outro. Segundo sugere o diálogo, não há (auto)conhecimento nesse tipo de sedução. o que há nesse exercício seria apenas, pela

25 A edição de John Burnet da Platonis Opera (1903) sugere "enchanting" (encantador) como tradução para a expressão, no entanto em grego a expressão é $\kappa \varepsilon \kappa \eta \lambda \eta \mu \varepsilon ́ v o l$ (Prt. 315b1), e ela não tem referência direta com a expressão $\dot{\epsilon} \pi \omega \delta \dot{\eta}$ (Chrm. 155e5), por isso a melhor proposta de tradução para a expressão é "sedução/sedutor" e não "encantação/encantador". 
musicalidade das palavras e do discurso, o encantamento do ouvinte. 0 problema é que a informação discurso pode conter riscos para a própria saúde do indivíduo e da polis; nesse sentido, também para o cosmos. ${ }^{26}$

O erro do sofista, no Protágoras, estaria na tentativa de fazer parecer possível a mudança da psyche de seu ouvinte de fora para dentro, como mágica. Da mesma maneira que o sofista não pode tirar a psyche humana da obscuridade no Protágoras, Orfeu não pode tirar Eurídice do Hades no Banquete, pois ambos trabalhariam com o encantamento sem (auto)conhecimento.

A psyche, obscurecida, não pode ser retirada de sua obscuridade por um elemento externo a ela, seja esse elemento uma divindade ou um discurso sofista, ou ainda um ritual, ou mesmo o álcool (que pode ser apenas um auxílio externo). A psyche precisa mergulhar-se em si própria, assumindo e buscando conhecer sua própria obscuridade. Platão não nega a possibilidade de um auxílio externo, mas tudo que é externo é apenas um mote inspirador e direcionador para a katabasis subjetiva que leva a psyche ao (auto)conhecimento, nunca a causa de (auto)conhecimento.

\section{2- KATABASIS E A PROBLEMÁTICA DA AUTOSSALVAÇÃO}

Segundo a tradição mítica, Orfeu tem capacidade de exercer poderes encantatórios até mesmo sobre animais e seres inanimados. Este mote certamente facilitou a difusão da versão de sua descida ao Hades para resgatar sua amada Eurídice depois de encantar os deuses do julgamento e da morte.

26 Bernabé diz a esse respeito: "Platão quer sugerir que a retórica de Protágoras gera em seus ouvintes uma concordância quase hipnótica, que desvia da busca filosófica da verdade, como o canto mágico de Orfeu pode seduzir, mas não ajuda a chegar à verdade. Deste modo, então, ao situá-lo como precursor da sofística, Platão alinha as doutrinas de Orfeu com a dos novos intelectuais de Atenas no âmbito da aparência ( $\delta$ ́́ $\alpha)$, oposta à verdade" (Bernabé 2011: 41-42). 
Na recriação que Platão faz de Orfeu no Banquete, todavia, Fedro, personagem, relata o feito órfico de uma maneira bastante diferente da variante tradicional que diz da vitória em seu intento de resgatar Eurídice. No diálogo, Orfeu consegue, sim, descer ao Hades, mas consegue apenas ver a imagem de Eurídice, mas não sua verdadeira psyche. ${ }^{27}$

A referência ao fato de os deuses "terem mostrado o fantasma da mulher" (Smp. 179d) ${ }^{28}$ a Orfeu sustenta a ideia de que Orfeu não pode resgatar sua amada Eurídice do Hades porque nenhum ente pode resgatar a psyche de outro ente de sua obscuridade. Por isso os deuses, fingindo ter sido encantados por Orfeu, castigam-no apresentando-lhe apenas a imagem de Eurídice.

Nos textos homéricos, a psyche é apresentada como um tipo de imagem fantasmagórica, sem cognoscência: "Ora a certeza adquiri de que no Hades, realmente, se encontram / almas e imagens ${ }^{29}$ dos vivos, privadas, contudo, de alento" (Hom. Il. 23, vv. 103-104) ${ }^{30}$.

E em sua versão de que os deuses devolvem engano com engano está a sua ideia de que não é recorrendo a recursos formais, externos, nem ao ensinamento enganoso dos poetas, nem, como veremos, a rituais mais ou menos mágicos, que o homem pode conquistar uma situação privilegiada no Além (Bernabé 2011: 47).

27 Cf. Banquete (179d2-7).

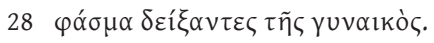

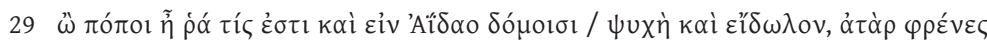

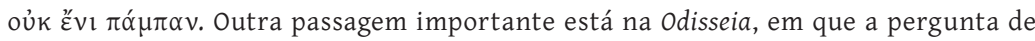
Ulisses à psyche de Aquiles revela a condição de mera "imagem" das almas no Hades:

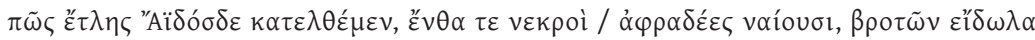

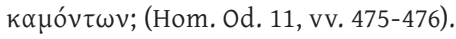

30 A palavra psyche é associada, em Homero, à "imagem do morto privada de consciência e de inteligência" (Reale 2002: 70) - um elemento que esvai, que sai do corpo pela ferida ou pela boca, após a morte. A psyche "enquanto 'sombra' (eidolon), 'imagem espectral', sem sensibilidade nem conhecimento, não é o 'eu' do homem, mas, poder-se-ia dizer, o ‘não-ser-mais-do-eu', ou o ‘eu-que-não-é-mais’” (Reale 2002: 74). o significado de psyche em Homero, pode ser reduzido "em grande parte, a dois: (a) 'sombra' e (b) 'vida', 'força vital' ou 'entidade vivificadora' que encontra o seu fim quando morremos” (Robinson 2010: 17). 
Dito de outra maneira, nenhuma psyche pode ser melhorada por uma força externa a ela, mas apenas auxiliada por uma força externa. Por isso Orfeu não consegue resgatar Eurídice do Hades no Banquente. Platão busca, com isso, sustentar que operamos com sombras, quando buscamos encantamentos externos superficiais de fora para dentro, e, nesse sentido, nenhuma mudança psíquica é verdadeiramente uma mudança de disposição de caráter.

Assim, a katabasis objetiva de Orfeu para resgatar Eurídice do Hades, realizada por uma descida literal, é alterada por uma katabasis subjetiva, em Platão, fundamentada por uma ideia de ação moral praticada por cada psyche. Ou melhor, a descida passa a ser uma ação subjetiva, em que o agente de purificação e mudança é a própria psyche.

Se, por um lado, Fedro tenta chamar atenção para o poder de Orfeu de comover e, consequentemente, convencer os deuses ínferos, por outro lado Sócrates chama atenção para seu fracasso.

A declaração de Admeto, nas circunstâncias descritas na tragédia de Eurípides, não é senão uma patética demonstração de egoísmo que toca o ridículo: o valente Alceste que aceita a morte se contrapõe ao covarde Admeto, que a deixa morrer em seu lugar e que, vale dizer, tem o cinismo de declarar que desejaria ter a possibilidade de ir vivo ao Hades por ela. Platão assume essa contraposição; no entanto, os seus termos são agora Alceste e o próprio Orfeu, convertido assim mesmo no paradigma da covardia. Covardia de poeta que não foi capaz de morrer por amor.

Platão, entretanto, não pára por aí, e desenvolve este motivo no sentido de que os deuses castigam a covardia de Orfeu com um engano, substituindo sua amada por uma mera imagem (Bernabé 2011: 48).

Há outro ponto que resulta da falência da katabasis de Orfeu no Banquete, já que Orfeu não é a causa da ventura ou da desventura de uma alma no Além. Cada um só pode, na recriação do mito de Orfeu em Platão, salvar-se ou condenar-se a si próprio por meio de suas próprias ações. O filósofo ateniense busca negar a ideia de que, por meio 
mágico e ritual, uma intervenção externa é a causa de condenação ou de salvação de uma psyche.

Pela ideia de katabasis subjetiva, o encantamento mágico é substituído pela busca do (auto)conhecimento, que promove harmonia, justiça e, por consequência, purificação psíquica. Nesse sentido, cada psyche é a única que pode salvar-se a si própria. Para isso, todavia, Platão, na sequência do diálogo, abre longa discussão a respeito da possibilidade de a sabedoria poder ou não ser transmitida para outrem.

A ironia de Sócrates, percebida por Ágaton, indica que não é possível a sabedoria ser transferida do "mais cheio" para o "mais vazio" como água que corre de um copo cheio para um copo vazio por um fio de lã. A sabedoria não perfaz esse caminho. o processo de sabedoria tem sua transformação no interior da psyche. Não é possível, portanto, o sábio transferir sabedoria a alguém, da mesma maneira que não é possível alguém salvar da obscuridade a psyche de outrem. Este alguém deve, em sua própria psyche, dar início ao processo de mergulho em si própria, por meio de profunda reflexão. o que o sábio pode fazer é indicar caminhos a psyche de outrem, direcionando-a para que ela consiga alcançar seu próprio mergulho, buscando, assim, o (auto)conhecimento.

Sócrates então senta-se e diz: - Seria bom, Agatão, se de tal natureza fosse a sabedoria que do mais cheio escorresse ao mais vazio, quando um ao outro nos tocássemos, como a água dos copos que pelo fio de lã escorre do mais cheio ao mais vazio (Smp. $175 \mathrm{~d})^{31}$.

\section{(...)}

Se é assim também a sabedoria, muito aprecio reclinar-me ao teu lado, pois creio que de ti serei cumulado com uma vasta e bela sabedoria. A minha seria um tanto ordinária, ou mesmo duvidosa como um sonho, enquanto que a tua é brilhante e muito desenvolvida, ela que de tua

31 Trad. de Sousa (1972). 
mocidade tão intensamente brilhou, tornando-se anteontem manifesta a mais de trinta mil gregos que a testemunharam (Smp. 175e) ${ }^{32}$.

A defesa sofista de que a sabedoria pode ser transferida é recusada por Platão, já que ela visa apenas ao encantamento vazio pelas palavras vazias e não à mudança verdadeira da psyche. Pelo mesmo motivo, Orfeu não pode salvar Eurídice, e, se assim é, também não poderia salvar nenhuma das psychai humanas. Por isso Platão recria a katabasis órfica segundo um completo fracasso de Orfeu quanto ao resgate de Eurídice. No livro décimo da República, Platão explora bastante bem essa ideia de responsabilidade psíquica, ao recriar, no mythos de Er, algumas ideias órficas. Nesse relato, a psyche tem sobre seu próprio destino o poder de decisão. Enquanto para a tradição órfica o destino da alma é dada pelas divindades do Hades, no relato de Er a vida de "cada uma das almas" ( $R$. 10, 619e6-620a1) 33 "era escolhida" (R. 10, 620a1) $)^{34}$ "segundo o intercurso dos hábitos da vida" (R. 10, 620a2-3) ${ }^{35}$. Coutinho (2016: 69-71) elucida a esse respeito que Platão não está disposto a aceitar a passividade transmigratória aceita pelo(s) orfismo(s), por isso faz sua personagem assumir a ideia de que é a alma que escolhe seu próprio destino e não as divindades. Platão pretende, com isso, sustentar a teoria de que cada ser humano determina seu próprio futuro psíquico de acordo com seus vícios e/ou suas virtudes. E reconhecer os próprios hábitos de vida significa alcançar o (auto)conhecimento que o possibilitará a uma verdadeira mudança de disposição de caráter.

32 Trad. de Sousa (1972).

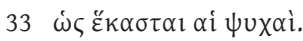

34 ท่คoũvนo.

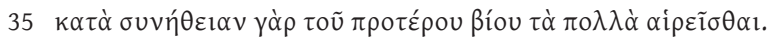




\section{BIBLIOGRAFIA}

\section{FONTES PRIMÁRIAS}

Aristófanes. As Rãs. Trad. Maria de Fátima Silva. Imprensa da Universidade de Coimbra/ Annablume, 2014.

Eurípides. Alcestes; In Eurípides Tragédias I. Trad. Nuno Simões Rodrigues. FLUC/ Imprensa Nacional Casa da Moeda, Lisboa, 2009.

-. As bacantes. Trad. Maria Helena da Rocha-Pereira. Eurípides. Edições 70, Lisboa, 2014.

-. Ifigénia em Aulis. Trad. Carlos Alberto Pais de Almeida (Introdução de Maria de Fátima e Silva). Festea, 2008.

Heródoto. Histórias. Trad. Pierre Henri Larcher. eBooksBrasil, 2006.

Homero. Odisseia. Trad. Frederico Lourenço. Cotovia, Lisboa, 2012.

Íbico de Régio.

Platão. Obras completas de Platón. Trad. Patricio de Azcárate. Medina e Navarro, Madrid. 1871-1972. 1870, eBook 2008

-. Plato in Twelve Volumes. Cambridge, MA, Harvard University Press, London, 1921 a 1969.

-. Tutti gli scritti. Traduzione di Giovanni Reale. Bompiani, Milano, 2008.

Siculo, Diodoro. Storia Universale, Tomo I. A cura di Vicenzo Pogoioli. Via dell’Anima, no 10, Roma, 1813. Disponível <http://www.bodleian.ox.ac. uk/ dbooks> em 23 de abril de 2012.

\section{FONTES SECUNDÁRIAS}

Bernabé, Alberto (2011). Platão e o orfismo - diálogo entre religião e filosofia. Annablume, São Paulo.

- (2007). "El silencio entre los órficos"; In Ilu. Revista de Ciencias de las Religione 19: 53-66. 
Burnet, John (1919). Early Greek Philosophy. Adam and Charles Black, London.

Burkert, Walter (1983). Homo Necans. The Anthropology of Ancient Greek Sacrificial Ritual and Myth. Berkeley, Los Angeles, London.

Casadesús, Francesc (2008). “Orfeu y orfismo en Platón”; In Bernabé-Casadesús (eds), 1239-1279.

Coutinho, Luciano (2016). "A recriação do orfismo no mythos de Er: a descoberta da escolha do futuro da psyche em Platão" in Cosmópolis: mobilidades culturais às origens do pensamento. Coimbra / São Paulo. Coimbra University Press / Annablume, 65-74.

- (2015a). "O Crítias oracular e a psicologia de Sócrates: temperança no Cármides de Platão" in Boletim de Estudos Clássicos 61: 33-44.

- (2015b). Katabasis e psyche em Platão. Tese $304 f$ (Doutorado em Estudos Clássicos / Filosofia Antiga). Instituto de Estudos Clássicos, Universidade de Coimbra, Coimbra.

Dodds, Eric Robertson (2002). Os Gregos e o Irracional. Trad. Paulo Domenech Oneto. Escuta, São Paulo. (1ª ed. 1951).

Guthrie, William K. C. (2003). Orfeo y la religión griega. Trad. Juan Valmard. Ediciones Siruela, Madrid.

Iglesias, Maura (1998). "Platão: a descoberta da alma"; In Boletim do CPA, Campinas, 5/6: 13-60.

Kahn, Charles (1997). "Was Euthyphro the Author of the Derveni Papyrus?". eds. LaksMost, 55-63.

Macías, Sara (2008). Orfeu y el orfismo en Eurípides. Tesis Doctoral, Universidade Complutense.

Reale, Giovanni (2002). Corpo, Alma e Saúde - O Conceito de Homem de Homero a Platão. Trad. Marcelo Perine. Paulus, São Paulo.

Robinson, Thomas M. (2010). As origens da alma: Os gregos e o conceito de alma de Homero a Aristóteles. Annablume, São Paulo. 